[Review Paper]

\title{
Molybdenum Catalysts for Synthesis of Mixed Alcohols from Synthesis Gas
}

\author{
Takashi Tatsum ${ }^{*}$, Atsushi Muramatsu, and Hiro-o Tominaga \\ Dept. of Synthetic Chemistry, Faculty of Engineering, The University \\ of Tokyo, 7-3-1 IIongo, Bunkyo-ku, Tokyo 113
}

(Received September 11, 1991)

\begin{abstract}
Highly active Mo catalysts for synthesis of mixed alcohols from synthesis gas were prepared using $\mathrm{SiO}_{2}$ as a carrier. $\mathrm{KCl}$ promoted the selectivity to alcohols but reduced $\mathrm{CO}$ conversions, in particular, to hydrocarbons. High specific activity of $420 \mathrm{~g}(\mathrm{~kg} \text {-catalyst })^{-1} \cdot \mathrm{h}^{-1}$ was attained at $5.0 \mathrm{MPa}, 573 \mathrm{~K}$, and $W / F=1.4 \mathrm{~g}$-catalyst $\cdot \mathrm{h} \cdot \mathrm{mol}^{-1}$. The alcohol formation was found to require two kinds of Mo species, metallic Mo and $\mathrm{MoO}_{2}$, after reduction with flowing $\mathrm{H}_{2}$. The presence of $\mathrm{K}$ prevented the complete reduction of Mo to metal, resulting in increased production of alcohols. Marked increase in alcohol yield with time on stream indicated that active species for alcohol synthesis were formed during the CO hydrogenation. From the study of the effect of pretreatment of $\mathrm{Mo}$ catalysts with $\mathrm{CO}, \mathrm{CO}-\mathrm{H}_{2}$, and butane- $\mathrm{H}_{2}$, and Mo $3 d$ XPS, it has been concluded that the formation of CO-reduction induced defects on $\mathrm{MoO}_{2}, \mathrm{MoO}_{2-x}$, during the $\mathrm{CO}$ hydrogenation reaction, is the cause of the increase in the alcohol synthesis rate. On the other hand, the hydrocarbon synthesis appeared to be solely based on metallic Mo. From the study of addition of probe molecules to $\mathrm{CO}-\mathrm{H}_{2}$, it has been clarified that the higher alcohol formation from $\mathrm{CO}-\mathrm{H}_{2}$ proceeded by way of the same intermediate as the alkene hydrocarbonylation. A dual-site mechanism for the alcohol formation over $\mathrm{SiO}_{2}$-supported Mo has been proposed: $\mathrm{CO}$ dissociates on metallic Mo to form surface carbide, followed by hydrogenation of carbene and/or methyl species. While addition of methylene unit to surface alkyl species and following hydrogenolysis and/or dehydrogenation of alkyls to give hydrocarbons also occur on metallic Mo, CO insertion leading to alcohols is catalyzed by $\mathrm{MoO}_{2-x}$ species. It has been found that $\mathrm{K}$ is effective in retarding hydrogenolysis of alkyls, improving the selectivity to alcohols. The mechanism can account for the difference in selectivities to branched products between hydrocarbons and alcohols.
\end{abstract}

\section{Introduction}

The catalytic conversion of synthesis gas to oxygenated compounds, alcohols, in particular, is generally recognized as an interesting route for providing clean fuels and chemical feedstocks. The most promising application of the $\mathrm{C}_{1}-\mathrm{C}_{5}$ mixed alcohols is a blending stock for automotive fuel to meet the octane number requirement ${ }^{1), 2)}$. Problems caused by the use of methanol (phase separation, vapor lock, etc.) can be alleviated by incorporating $\mathrm{C}_{2}+$ higher alcohols as a cosolvent into the methanol-gasoline mixture. Several investigators reported that an appropriate modification of the methanol synthesis catalyst resulted in the formation of higher alcohols together with methanol1) 3). Institut Francais de Petrole and Idemitsu patented catalysts for mixed alcohol synthesis, composed of methanol synthesis catalysts $(\mathrm{Cu})$ and Fischer-Tropsch ${ }^{4)}$ or methanation ${ }^{5)}$

* To whom correspondence should be addressed. catalysts.

Molybdenum catalysts have long been recognized as being effective for the methanation and/or Fischer-Tropsch synthesis of light hydrocarbons6) ${ }^{6)}$. Our previous study, however, revealed that silica-supported molybdenum catalysts were active in the production of $\mathrm{C}_{1}-\mathrm{C}_{5}$ mixed alcohols ${ }^{10) ~ 14)}$. The addition of $\mathrm{KCl}$ to $\mathrm{Mo} / \mathrm{SiO}_{2}$ resulted in a significant increase in the selectivity to alcohol formation. It was also found that the sequence of impregnation profoundly affected the activity and selectivity to alcohols ${ }^{12)}$. In this regard it should be noted that Dow and Union Carbide have published a number of patents of the catalysts based on $\mathrm{MoS}_{2}$, promoted by $\mathrm{CoS}$ and alkali metal salts, for higher alcohol synthesis ${ }^{15}$.

The objectives of this study are (1) to investigate improved design of catalysts and the effects of reaction conditions for the mixed alcohol synthesis and (2) to pursue the mechanism for the formation of alcohols and the active species for alcohol production. 


\section{Preparation and Pretreatment of $\mathrm{Mo} / \mathrm{SiO}_{2}$ Catalysts}

\section{1 Mo Species on Freshly Reduced Catalysts}

Catalysts were prepared by impregnating silicagel (Fuji Davison ID) with an aqueous solution of $\left(\mathrm{NH}_{4}\right)_{6} \mathrm{Mo}_{7} \mathrm{O}_{24} \cdot 4 \mathrm{H}_{2} \mathrm{O}$. For promoted catalysts, $\mathrm{KCl}$ or $\mathrm{Rb}_{2} \mathrm{CO}_{3}$ was added to the silica first, followed by air calcination at $673 \mathrm{~K}$ for $\mathrm{l} \mathrm{h}$ and impregnation with the molybdenum salt. Unless otherwise noted, the impregnates were dried at $393 \mathrm{~K}$ overnight and treated in flowing $\mathrm{He}$ at $673 \mathrm{~K}$ for $\mathrm{l} \mathrm{h}$ and then reduced in flowing $\mathrm{H}_{2}$ for $12 \mathrm{~h}$.

The oxidation state of molybdenum naturally lowers on raising the reduction temperature. Saito and Anderson reported that small peaks of Mo metal were found in an X-ray diffraction pattern following reduction of unsupported $\mathrm{MoO}_{3}$ with $\mathrm{H}_{2}$ at $673 \mathrm{~K}$ and that Mo metal was obtained by the reduction at $873 \mathrm{~K}^{7}$.

The effect of temperature for $\mathrm{H}_{2}$ reduction on the characteristics of $\mathrm{SiO}_{2}$-supported molybdenum catalysts has been investigated. Table 1 lists $\mathrm{O}_{2}$ adsorption uptakes, phases observed by X-ray diffractograms (XRD), and average oxidation numbers of $\mathrm{Mo}$ after $\mathrm{H}_{2}$ reduction (before exposure to synthesis gas). Strong X-ray lines corresponding to metallic Mo and weak lines characteristic of $\mathrm{MoO}_{2}$ appeared on the catalyst reduced at $873 \mathrm{~K}$. On decreasing the reduction temperature, the intensity of the $\mathrm{MoO}_{2}$ lines increased at the expense of metallic Mo lines. On the catalyst reduced at $673 \mathrm{~K}$, metallic Mo lines could be hardly observed. Average oxidation number estimated by $\mathrm{O}_{2}$ titration was in agreement with the XRD observation. The influence of $\mathrm{K}$ content on the surface characteristics of the fresh catalyst are also shown in Table 1. The presence of $\mathrm{K}$ effectively prevented the complete reduction of molybdenum to metal. $\mathrm{O}_{2}$ adsorption uptakes for the catalysts at $195 \mathrm{~K}^{16)}$ suggest that the Mo dispersion decreases sharply on addition of $\mathrm{K}$ but is insignificantly affected by the reduction temperature.

The influence of the reduction temperature and $\mathrm{K}$ content on activity in $\mathrm{CO}$ hydrogenation is shown in Table 2. The CO hydrogenation was carried out in a flow reactor made of stainless steel tube. As expected from the water-gas shift activity of Mo catalysts7), these catalysts yielded $\mathrm{CO}_{2}$ almost exclusively instead of water as the coproduct (vide infra). In Table 2, specific activities in $\mathrm{g}$ ( $\mathrm{kg}$-catalyst $)^{-1} \cdot \mathrm{k}^{-1}$ were used to compare alcohol synthesis activities. Clearly there are marked differences between these catalysts, the low conversion of $\mathrm{CO}$ on the catalyst reduced at $673 \mathrm{~K}$ being the most noticeable. $\mathrm{CO}$ conversion increased as the reduction temperature increased. The activity for hydrocarbon formation and the ratio of alkene to alkane also increased. The catalyst reduced at $873 \mathrm{~K}$ exhibited the highest activity and selectivity for $\mathrm{C}_{2}+$ hydrocarbons. Best results in terms of the activity and selectivity for alcohol synthesis were obtained for the catalyst

Table 1 Influence of Reduction Temperature and K Content on Surface Characteristics of $\mathrm{Mo} / \mathrm{SiO} 2$ Catalysts

\begin{tabular}{|c|c|c|c|c|c|c|}
\hline \multirow{2}{*}{$\begin{array}{c}\text { Mo } \\
\text { loading } \\
{[\mathrm{wt} \%]}\end{array}$} & \multirow{2}{*}{$\begin{array}{l}\mathrm{K} / \mathrm{Mo} \\
\text { ratio }\end{array}$} & \multirow{2}{*}{$\begin{array}{c}\text { Reduction } \\
\text { temperature } \\
{[\mathrm{K}]}\end{array}$} & \multicolumn{2}{|c|}{$\begin{array}{l}\text { XRD phases } \\
\text { after reduction }\end{array}$} & \multirow{2}{*}{$\begin{array}{c}\mathrm{O}_{2} \text { adsorption } \\
\text { uptake } \\
{\left[\mu \mathrm{mol} \cdot(\mathrm{g} \text {-cat. })^{-1}\right]}\end{array}$} & \multirow{2}{*}{$\begin{array}{l}\text { Apparent } \\
\text { oxidation } \\
\text { number }^{\text {b }}\end{array}$} \\
\hline & & & $\mathrm{MoO}_{2}$ & Metallic Mo & & \\
\hline 5 & 0.4 & 673 & strong & not detected & 90 & 3.4 \\
\hline 5 & 0.4 & 773 & medium & medium & 80 & 2.0 \\
\hline 5 & 0.4 & 873 & weak & strong & 70 & 1.3 \\
\hline 20 & 0 & 773 & weak & very strong & 530 & \\
\hline 20 & 0.2 & 773 & medium & strong & 140 & \\
\hline 20 & 0.3 & 773 & medium & medium & 160 & \\
\hline 20 & 0.4 & 773 & strong & weak & 130 & \\
\hline
\end{tabular}

a): Measured at $195 \mathrm{~K}$

b): Estimated from $\mathrm{O}_{2}$ consumption from 195 to $773 \mathrm{~K}$.

Table 2 Influence of Reduction Temperature and K Content on Performance of $\mathrm{Mo} / \mathrm{SiO} 2$ Catalysts

\begin{tabular}{|c|c|c|c|c|c|c|c|c|c|}
\hline \multirow{3}{*}{$\begin{array}{c}\text { Mo } \\
\text { loading } \\
{[\mathrm{wt} \%]}\end{array}$} & \multirow{3}{*}{$\begin{array}{l}\mathrm{K} / \mathrm{Mo} \\
\text { ratio }\end{array}$} & \multirow{3}{*}{$\begin{array}{c}\text { Reduction } \\
\text { temperature } \\
{[\mathrm{K}]}\end{array}$} & \multirow{3}{*}{$\begin{array}{c}\mathrm{CO} \\
\text { conv. } \\
{[\%]}\end{array}$} & \multirow{3}{*}{$\begin{array}{c}\mathrm{CO}_{2} \\
\text { yield } \\
{[\%]}\end{array}$} & \multicolumn{2}{|c|}{ Activity } & \multirow{2}{*}{\multicolumn{2}{|c|}{$\begin{array}{c}\mathrm{C}_{2}+/ \mathrm{C}_{1} \\
\text { Molar ratio }\end{array}$}} & \multirow{3}{*}{$\begin{array}{c}\text { Olefin } \\
\text { content in } \mathrm{C}_{3} \\
{\left[\begin{array}{l}\% \\
\%]\end{array}\right.}\end{array}$} \\
\hline & & & & & \multirow{2}{*}{$\begin{array}{l}\text { Alcohols } \\
\text { lge(kg-cat. }\end{array}$} & \multirow{2}{*}{$\begin{array}{l}\mathrm{HC}^{\mathrm{a})} \\
\left.\cdot \mathrm{h}^{-1}\right]\end{array}$} & & & \\
\hline & & & & & & & Alcohols & $\left.H C^{a}\right)$ & \\
\hline 5 & 0.4 & 673 & 1.9 & 0.96 & 2.6 & 5.3 & 1.1 & 1.2 & 39 \\
\hline 5 & 0.4 & 773 & 8.2 & 3.8 & 17 & 25 & 2.1 & 1.3 & 65 \\
\hline 5 & 0.4 & 873 & 12 & 6.5 & 14 & 34 & 2.9 & 1.8 & 87 \\
\hline 20 & 0 & 773 & 31 & 18 & 1.4 & 140 & 0.49 & 1.4 & 11 \\
\hline 20 & 0.2 & 773 & 11 & 5.0 & 22 & 34 & 1.1 & 1.4 & 51 \\
\hline 20 & 0.3 & 773 & 5.8 & 2.5 & 20 & 13 & 2.2 & 1.7 & 72 \\
\hline 20 & 0.4 & 773 & 3.4 & 1.4 & 14 & 5 & 2.3 & 1.7 & 78 \\
\hline
\end{tabular}

Reaction conditions; $573 \mathrm{~K}, 1.6 \mathrm{MPa}\left(\mathrm{H}_{2} / \mathrm{CO}=1\right), W / F=10 \mathrm{~g}$-catalyst $\cdot \mathrm{h} \cdot \mathrm{mol}^{-1}$

a): IIydrocarbons. 
reduced at $773 \mathrm{~K}$. The $\mathrm{C}_{2}+$ alcohols/methanol ratio increased on raising the reduction temperature.

The effect of $\mathrm{K}$ content on the catalytic performance of $\mathrm{Mo} / \mathrm{SiO}_{2}$ will be summarized as follows. With increasing the $\mathrm{K}$ content, the selectivity to alcohols increased at the expense of $\mathrm{CO}$ conversion, reaching $70 \mathrm{C}$-atom $\%$ at $\mathrm{K} / \mathrm{Mo}=$ 0.4. At the same time the $\mathrm{C}_{2}+/ \mathrm{C}_{1}$ ratios for alcohols and hydrocarbons increased and the alkene content increased.

Taking into account the findings of the XRD observation, the higher $\mathrm{CO}$ conversion seems to be related to the higher metallic Mo content in the catalysts $^{7}$. There was no clear relationship between $\mathrm{O}_{2}$ uptake and $\mathrm{CO}$ conversion. Reduction of Mo at higher temperature or in the absence of $\mathrm{K}$ resulted in the evolution of large amounts of metallic Mo, leading to the catalyst producing hydrocarbons predominantly. This is consistent with our previous findings on the effect of Mo precursors ${ }^{11)}$ and the order of impregnation with molybdenum and potassium salts ${ }^{12}$. The catalyst reduced at $673 \mathrm{~K}$ and with high $\mathrm{K}$ content, for which XRD patterns of metallic Mo phase could be hardly observed, showed very low activity for $\mathrm{CO}$ hydrogenation. Thus it is suspected that the presence of both metallic $\mathrm{Mo}$ and $\mathrm{MoO}_{2}$ species on the catalyst surface before exposure to synthesis gas is required to effect the production of alcohols and that there is an appropriate content of metallic Mo.

\section{2 Activity Change with Processing Time}

It has been shown that the presence of an adequate amount of metallic Mo and $\mathrm{MoO}_{2}$ on the freshly reduced catalyst is a prerequisite for the superior performance for alcohol synthesis. However, it is inconceivable that the species over the freshly reduced catalysts are directly responsible for the alcohol synthesis from synthesis gas because we found a rather long induction period for alcohol formation. The change in yields of alcohols, hydrocarbons, and $\mathrm{CO}_{2}$ over Mo (10 $\mathrm{wt} \%)-\mathrm{K}(1.63 \mathrm{wt} \%) / \mathrm{SiO}_{2}$, is illustrated in Fig. 1 . In the initial stage of the $\mathrm{CO}-\mathrm{H}_{2}$ reaction the yield of alcohols was surprisingly low. The activity for alcohol formation remarkably increased with time on stream and reached a steady state level after $c a$. $15 \mathrm{~h}$. This implies that active species for alcohol production are formed during the $\mathrm{CO}-\mathrm{H}_{2}$ reaction. In contrast, the yield of $\mathrm{CO}_{2}$ was remarkably high at the initial stage of the reaction and decreased to reach a nearly steady state after $c a .15 \mathrm{~h}$ on stream. The yield of hydrocarbons gradually decreased and leveled off after $8 \mathrm{~h}$ on stream.

As mentioned above, Mo catalysts are active in $\mathrm{CO}$ shift reaction (Eq. (5)) to form $\mathrm{CO}_{2}$; under



Catalyst: $\operatorname{Mo}(10 \mathrm{wt} \%)-\mathrm{K}(1.63 \mathrm{wt} \%) / \mathrm{SiO}_{2} ; \quad$ Reaction conditions: $523 \mathrm{~K}, 1.6 \mathrm{MPa}\left(\mathrm{H}_{2} / \mathrm{CO}=\mathrm{l}\right), W / F=10$ g-cat. $\mathrm{h} \cdot \mathrm{mol}^{-1}$.

Fig. I Change in Product Yields with Processing Time

conditions employed in this study, the equilibrium conversion of Eq. (5) was estimated at $97 \%$ at $573 \mathrm{~K}$. Almost all of the oxygen which had been included in $\mathrm{CO}$ left the reactor as $\mathrm{CO}_{2}$ (Eqs. (3) and (4)) rather than as $\mathrm{H}_{2} \mathrm{O}$ (Eqs. ( 1 ) and (2)). As shown in Fig. 1, at the steady state the yield of $\mathrm{CO}_{2}$ was found to be in good agreement with the combined yield of hydrocarbons and alcohols, assuming the equilibrium in the $\mathrm{CO}$ shift reaction (Eq. (5)). In the initial stage of the $\mathrm{CO}-\mathrm{H}_{2}$ reaction, however, the yield of $\mathrm{CO}_{2}$ noticeably exceeded the yield of alcohols and hydrocarbons. The formation of excess of $\mathrm{CO}_{2}$ should be ascribed to Boudouard reaction (Eq. (6)) or reduction of $\mathrm{MoO}_{2}$ by $\mathrm{CO}$ (Eq. (7)). It should be noted that there was a coincidence between the times required to reach the steady-state of alcohol synthesis and $\mathrm{CO}_{2}$ formation.

$$
\begin{aligned}
& n \mathrm{CO}+2 n \mathrm{H}_{2} \rightarrow-\left(\mathrm{CH}_{2}\right)_{n^{-}}+n \mathrm{H}_{2} \mathrm{O} \\
& n \mathrm{CO}+2 n \mathrm{H}_{2} \rightarrow \mathrm{CH}_{3}\left(\mathrm{CH}_{2}\right)_{n-1} \mathrm{OH} \\
& +(n-1) \mathrm{H}_{2} \mathrm{O} \\
& 2 n \mathrm{CO}+n \mathrm{H}_{2} \rightarrow-\left(\mathrm{CH}_{2}\right)_{n^{-}}+n \mathrm{CO}_{2} \\
& (2 n-1) \mathrm{CO}+(n+1) \mathrm{H}_{2} \rightarrow \\
& \mathrm{CH}_{3}\left(\mathrm{CH}_{2}\right)_{n-1} \mathrm{OH}+(n-1) \mathrm{CO}_{2} \\
& \mathrm{CO}+\mathrm{H}_{2} \mathrm{O} \rightarrow \mathrm{CO}_{2}+\mathrm{H}_{2} \\
& n \mathrm{Mo}+2 \mathrm{CO} \rightarrow \mathrm{Mo}_{n} \mathrm{C}+\mathrm{CO}_{2} \\
& \mathrm{MoO}_{2}+\mathrm{CO} \rightarrow \mathrm{MoO}_{2-x}+\mathrm{CO}_{2}
\end{aligned}
$$




\section{2. $3 \mathrm{CO}, \mathrm{CO}-\mathrm{H}_{2}$ and Carburizing Treatment}

A control experiment was carried out in which $\mathrm{Mo}(5 \mathrm{wt} \%)-\mathrm{K}(0.83 \mathrm{wt} \%) / \mathrm{SiO}_{2}$ catalyst reduced in $\mathrm{H}_{2}$ at $773 \mathrm{~K}$ for $12 \mathrm{~h}$ was further treated in flowing $\mathrm{CO}$ at $523 \mathrm{~K}, 0.1 \mathrm{MPa}$, and $W / F=10 \mathrm{~g}$-catalyst $\cdot \mathrm{h} \cdot$ mol-1 $^{-1}$ for $20 \mathrm{~h}$, left under $\mathrm{H}_{2}$ stream at $773 \mathrm{~K}$ until $\mathrm{CH}_{4}$ formation virtually ceased, and subjected to $\mathrm{CO}-\mathrm{H}_{2}$ reaction ${ }^{17)}$. The change in the yield of alcohols over the untreated catalyst and the catalyst treated by a flow of $\mathrm{CO}$ is illustrated in Fig. 2. The initial rate of alcohol formation is markedly higher over the $\mathrm{CO}$-treated catalyst than over the catalyst resulting from $\mathrm{H}_{2}$ reduction alone. Over the former catalyst, the rate of alcohol synthesis was virtually constant during the processing time up to $26 \mathrm{~h}$, while over the latter the rate after $40 \mathrm{~h}$ on stream was 20 times as high as that in the initial stage. Hence sites for alcohol synthesis appear to have been formed on the catalyst during the $\mathrm{CO}$ treatment. The amount of $\mathrm{CO}_{2}$ produced from the $\mathrm{CO}$ treatment was $117 \%$ based on the loaded Mo. We expect that the carbide formed according to Eq. (6) would react with $\mathrm{H}_{2}$ to form $\mathrm{CH}_{4}$. The $\mathrm{CH}_{4}$ formed by the successive $\mathrm{H}_{2}$ treatment accounted for only $46 \%$; a significant portion of $\mathrm{CO}_{2}$ seems to have been formed according to Eq. (7), resulting in the reduction of $\mathrm{MoO}_{2}$ to form oxygen defects according to Eq. (7).

The amount of $\mathrm{O}_{2}$ adsorption uptakes on the catalyst treated in $\mathrm{CO}$ and the untreated catalyst was 46 and $79 \mathrm{mmol}$ ( $\mathrm{g}$-catalyst) ${ }^{-1}$, respectively.

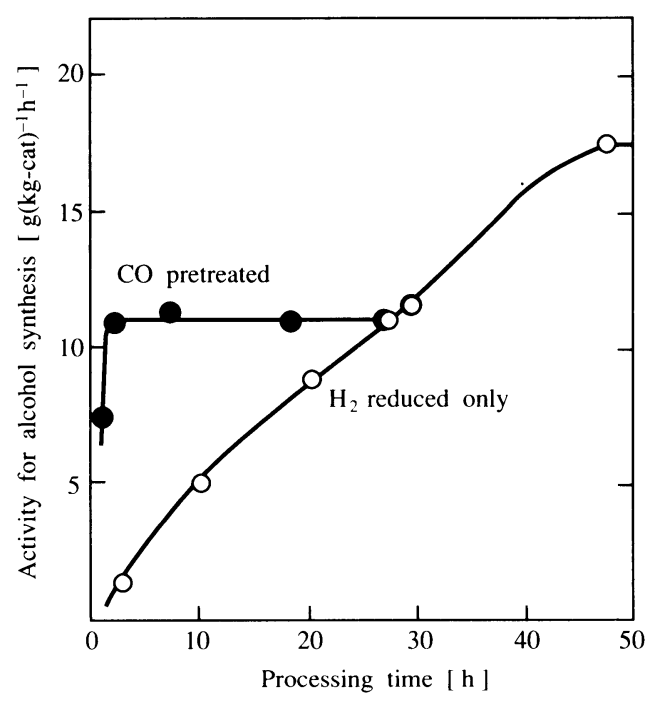

Catalyst: $\operatorname{Mo}(5 \mathrm{wt} \%)-\mathrm{K}(0.83 \mathrm{wt} \%) / \mathrm{SiO}_{2} ;$ Reaction conditions: $573 \mathrm{~K}, 1.6 \mathrm{MPa}\left(\mathrm{H}_{2} / \mathrm{CO}=\mathrm{l}\right), W / F=\mathrm{l} 0 \mathrm{~g}$-cat. $\cdot \mathrm{h}$. $\mathrm{mol}^{-1}$.

Fig. 2 Effect of CO Pretreatment on Change in Alcohol Yields with Processing Time
These two catalysts seem to have similar oxidation state and surface structures. Thus it is speculated that the lower activity of the CO-treated catalyst at the steady state would be explained by the lower dispersion of molybdenum. A linear correlation between $\mathrm{O}_{2}$ adsorption uptake and $\mathrm{CO}$ hydrogenation activity was established for unsupported $\mathrm{MoS}_{2}{ }^{18)}$.

Pretreatment of the reduced $\mathrm{Mo}-\mathrm{K} / \mathrm{SiO}_{2}$ catalyst with atmospheric $\mathrm{CO}-\mathrm{H}_{2}$ at $673 \mathrm{~K}$ resulted in similar enhancement of initial alcohol formation activity.

Mo carbides have been known to be very active in methanation of $\mathrm{CO}^{19), 20)}$. Hence one might wonder that the enhancement of alcohol synthesis activity during the $\mathrm{CO}-\mathrm{H}_{2}$ reaction and also by the $\mathrm{CO}$ or $\mathrm{CO}-\mathrm{H}_{2}$ treatment is due to the carburization of Mo. We have found that by carburizing the $\mathrm{H}_{2-}$ reduced catalyst with $\mathrm{C}_{4} \mathrm{H}_{10} / \mathrm{H}_{2}$, the initial activity for hydrocarbon formation was increased by a factor of 3, whereas the initial yield of alcohols was only slightly increased. The increase in hydrocarbon production is in agreement with the $\mathrm{X}$-ray powder patterns for the catalyst, which contained lines characteristic of $\mathrm{MO}_{2} \mathrm{C}$.

From these findings, we have ruled out the possibility that Mo carbides is directly related to the active site for alcohol synthesis. It may be concluded that the increase in alcohol production rate during the $\mathrm{CO}-\mathrm{H}_{2}$ catalytic run is ascribable to the formation of CO-reduction induced defects on $\mathrm{MoO}_{2}$ (Eq. (7)). It has been established that CO reduction induces defects in $\mathrm{ZnO}$ faces which

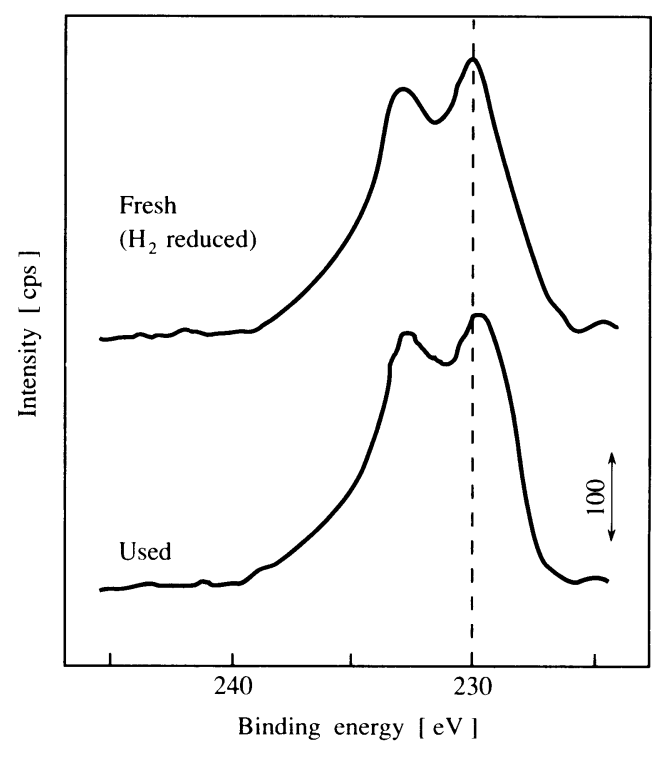

Fig. $3 \operatorname{Mo}(3 d)$ ESCiA Region of Fresh and Used $\mathrm{Mo}(10 \mathrm{wt} \%)-\mathrm{K}(1.63 \mathrm{wt} \%) / \mathrm{SiO}_{2}$ 
cannot be reduced with $\mathrm{H}_{2}$ and that these are specific sites for methanol synthesis ${ }^{21)}$. It has been recently proposed that the active site for hydrogenation of $\mathrm{CO}$ to methanol over $\mathrm{ZrO}_{2}$ is an oxygen anion vacancy ${ }^{22}$.

Figure 3 shows the Mo $3 d$ XPS peaks of fresh and used $\mathrm{Mo}-\mathrm{K} / \mathrm{SiO}_{2}$ catalysts. On the used catalyst there appeared a shoulder on the low binding energy side of the Mo $3 d_{5 / 2}$ peak, supporting that Mo oxides on the catalyst surface was partially reduced during the $\mathrm{CO}-\mathrm{H}_{2}$ reaction.

\section{Effects of Reaction Conditions}

As shown in Fig. 4, time factor $\left(W / F\right.$, g-catalyst ${ }^{*}$ $\mathrm{h} \cdot \mathrm{mol}^{-1}$ ) influenced on the selectivity to alcohols. Over the $\mathrm{Mo} / \mathrm{SiO}_{2}$ the selectivity of alcohols was improved at short contact time, suggesting a significant activity for the dehydration of alcohols to hydrocarbons under synthesis conditions. This is in agreement with the observation by Maruyama et al. ${ }^{23)}$, who reported that $\mathrm{Mo} / \mathrm{SiO}_{2}$ had significant acidity. For the catalyst with higher $\mathrm{K} /$ Mo ratio, however, the selectivity of alcohols was less dependent on the contact time ${ }^{24)}$. The contribution of the alcohol dehydration route to hydrocarbon formation seems to decrease on increasing the $\mathrm{K} / \mathrm{Mo}$ ratio.

The effect of total pressure on the product distribution over $\mathrm{Mo}(20 \mathrm{wt} \%)-\mathrm{K}(1.63 \mathrm{wt} \%) / \mathrm{SiO}_{2}$ at $573 \mathrm{~K}$ and $W / F=1.4 \mathrm{~g}$-catalyst $\cdot h \cdot \mathrm{mol}^{-1}$ is presented in Table 3. Raising the pressure, the yield of alcohols was greatly improved. The $\mathrm{C}_{2}+/ \mathrm{C}_{1}$ ratios of hydrocarbons and alcohols were independent of the pressure. It should be noted

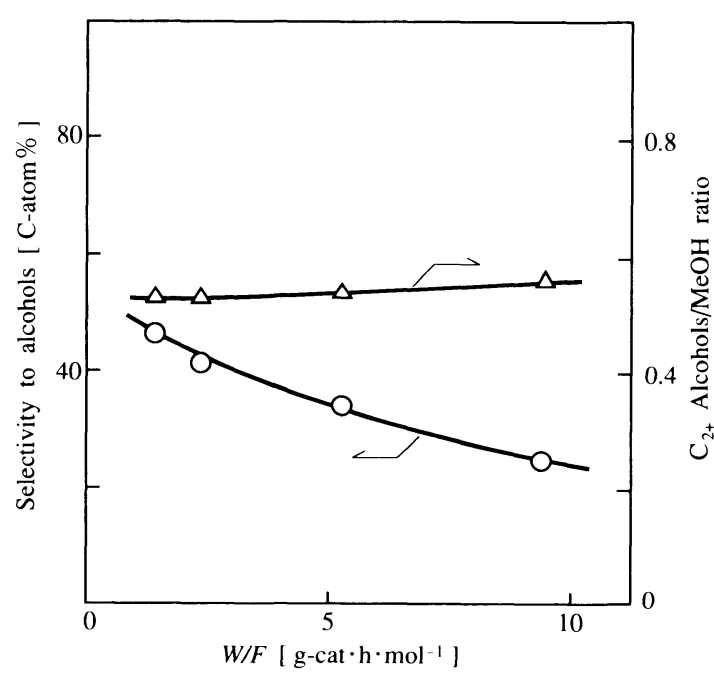

Catalyst: $\mathrm{Mo}(20 \mathrm{wt} \%)-\mathrm{K}(1.63 \mathrm{wt} \%) / \mathrm{SiO}_{2} ; \quad$ Reaction conditions: $573 \mathrm{~K}, 1.6 \mathrm{MPa}\left(\mathrm{H}_{2} / \mathrm{CO}=\mathrm{l}\right), W / F=10$ g-cat. $\mathrm{h} \cdot \mathrm{mol}^{-1}$.

Fig. 4 Influence of Time Factor on Alcohol Selectivity and $\mathrm{C}_{2}+$ Alcohols/Methanol Ratio

that at $5.0 \mathrm{MPa}$ specific activity of alcohols formation as high as $420 \mathrm{~g}$ ( $\mathrm{kg}$-catalyst $)^{-1} \cdot \mathrm{h}^{-1}$ was obtained in $68 \mathrm{C}$-atom\% selectivity. At $6.5 \mathrm{MPa}$ the selectivity to alcohols was slightly reduced, probably because of the dehydration of alcohols at increased contact time.

Table 4 shows the effect of reaction temperature on the catalytic performance of $\mathrm{Mo}(10 \mathrm{wt} \%)-\mathrm{K}(1.63$ $\mathrm{wt} \%) / \mathrm{SiO}_{2}$ at $1.6 \mathrm{MPa}$ and $W / F=10 \mathrm{~g}$-catalyst $\cdot \mathrm{h} \cdot$ $\mathrm{mol}^{-1}$. With lowering the temperature, the selectivity to alcohols was greatly improved. A

Table 3 Influence of Total Pressure on Performance of $\mathrm{Mo}(20 \mathrm{wt} \%)-\mathrm{K}(1.63 \mathrm{wt} \%) / \mathrm{SiO}_{2}$ Catalyst

\begin{tabular}{|c|c|c|c|c|}
\hline \multirow[b]{2}{*}{$\begin{array}{c}\text { Total pressure } \\
\qquad[\mathrm{MPa}]\end{array}$} & \multirow[b]{2}{*}{$\begin{array}{c}\mathrm{CO} \text { conversion } \\
{[\%]}\end{array}$} & \multirow[b]{2}{*}{$\begin{array}{c}\mathrm{CO}_{2} \text { yield } \\
{[\%]}\end{array}$} & \multicolumn{2}{|c|}{ Activity } \\
\hline & & & \multicolumn{2}{|c|}{$\left[\mathrm{g} \cdot(\mathrm{kg}-\mathrm{cat} .)^{-1} \cdot \mathrm{h}^{-1}\right]$} \\
\hline $\begin{array}{l}1.6 \\
5.0 \\
6.5\end{array}$ & $\begin{array}{l}2.7 \\
10 \\
13\end{array}$ & $\begin{array}{l}1.1 \\
3.1 \\
4.5\end{array}$ & $\begin{array}{r}72 \\
420 \\
428\end{array}$ & $\begin{array}{r}45 \\
124 \\
181\end{array}$ \\
\hline
\end{tabular}

Reaction conditions: $1.6 \mathrm{MPa}, \mathrm{H}_{2} / \mathrm{CO}=\mathrm{l}, W / F=1.4 \mathrm{~g}$-catalyst $\cdot \mathrm{h} \cdot \mathrm{mol}^{-1}$.

Table 4 Influence of Reaction Temperature on Performance of $\mathrm{Mo}(10 \mathrm{wt} \%)-\mathrm{K}(1.63 \mathrm{wt} \%) / \mathrm{SiO}_{2} \mathrm{Catalyst}$

\begin{tabular}{|c|c|c|c|c|}
\hline \multirow{2}{*}{$\begin{array}{l}\text { Reaction temperature } \\
\qquad[\mathrm{K}]\end{array}$} & \multirow{2}{*}{$\begin{array}{c}\text { CO conversion } \\
{[\%]}\end{array}$} & \multirow{2}{*}{$\begin{array}{c}\mathrm{CO}_{2} \text { yield } \\
{[\%]}\end{array}$} & \multicolumn{2}{|c|}{ Activity } \\
\hline & & & \multicolumn{2}{|c|}{$\left[\mathrm{g} \cdot(\mathrm{kg}-\mathrm{cat} .)^{-1} \cdot \mathrm{h}^{-1}\right]$} \\
\hline 513 & 0.32 & 0.10 & 2.2 & 0.41 \\
\hline 523 & 0.52 & 0.15 & 3.6 & 0.74 \\
\hline 538 & 1.0 & 0.33 & 6.7 & 1.7 \\
\hline 553 & 2.0 & 0.67 & 11 & 4.0 \\
\hline 573 & 5.5 & 2.3 & 21 & 12 \\
\hline 593 & 7.3 & 3.2 & 16 & 22 \\
\hline
\end{tabular}

Reaction conditions: $1.6 \mathrm{MPa}, \mathrm{H}_{2} / \mathrm{CO}=1, W / F=10$ g-catalyst $\cdot \mathrm{h} \cdot \mathrm{mol}^{-1}$. 
maximum yield of alcohols was obtained at $573 \mathrm{~K}$. $\mathrm{C}_{2}+$ alcohols/methanol ratio gradually increased with increasing the temperature.

\section{Addition of Probe Molecules to $\mathrm{CO}-\mathrm{H}_{2}$}

Table 5 shows the isomer distribution in alcohols and alkanes in $\mathrm{C}_{4}-\mathrm{C}_{6}$ range obtained with $\mathrm{Mo}(20 \mathrm{wt} \%)-\mathrm{K}(1.63 \mathrm{wt} \%) / \mathrm{SiO}_{2}$ at $573 \mathrm{~K}^{25)}$. The alcohols are exclusively primary, with some methyl branching in the 2-position, whereas hydrocarbons consist mainly of straight chain isomers. The former isomer distribution indicates a strong resemblance to that of the formation of alcohols and aldehydes by hydrocarbonylation of alkenes. Hence it is of special interest to examine the activity of Mo catalysts for hydrocarbonylation of alkenes ${ }^{24)}$.

Figure 5 shows the effects of ethene added (1.0$1.3 \mathrm{~mol} \%)$ to the $\mathrm{CO}-\mathrm{H}_{2}$ reactant gas on the yields of products at $473 \mathrm{~K}$ over $\mathrm{Mo}(20 \mathrm{wt} \%) / \mathrm{SiO}_{2}$ and $\mathrm{Mo}(20 \mathrm{wt} \%)-\mathrm{K}(1.63 \mathrm{wt} \%) / \mathrm{SiO}_{2}$. It is evident that over both catalysts the addition of ethene resulted in a marked increase in the l-propanol yield. This suggests the capability of Mo to catalyze CO insertion into surface ethyl-metal bond. Over the catalyst without $\mathrm{K}$ the yields of $\mathrm{C}_{3}$ hydrocarbons increased by the addition of ethene, suggesting incorporation of ethene into these compounds; the

Table 5 Isomer Distribution in Product Alcohols and Alkanes over $\mathrm{Mo}(20 \mathrm{wt} \%)-\mathrm{K}(1.63 \mathrm{wt} \%) / \mathrm{SiO}_{2}$

\begin{tabular}{|c|c|c|}
\hline \multirow{2}{*}{$\begin{array}{l}\text { Carbon } \\
\text { number }\end{array}$} & \multicolumn{2}{|c|}{ Isomer selectivity [mol\%] } \\
\hline & Alcohols & Alkanes \\
\hline 4 & $\begin{array}{c}\mathrm{CII}_{3}\left(\mathrm{CHI}_{2}\right)_{3} \mathrm{OHI} \\
68 \\
\mathrm{CII}_{3} \mathrm{CII}\left(\mathrm{CII}_{3}\right) \mathrm{CI} \mathrm{I}_{2} \mathrm{OHI} \\
32\end{array}$ & $\begin{array}{c}\mathrm{CII}_{3}\left(\mathrm{CH}_{2}\right)_{2} \mathrm{CHI}_{3} \\
93 \\
\left(\mathrm{CHH}_{3}\right)_{3} \mathrm{CH} \\
7\end{array}$ \\
\hline 5 & $\begin{array}{c}\mathrm{CH}_{3}\left(\mathrm{CH}_{2}\right)_{4} \mathrm{OH} \mathrm{I} \\
54 \\
\mathrm{C}_{2} \mathrm{H}_{5} \mathrm{CH}\left(\mathrm{CH}_{3}\right) \mathrm{CH}_{2} \mathrm{OH} \\
46\end{array}$ & $\begin{array}{c}\mathrm{CH}_{3}\left(\mathrm{CH}_{2}\right)_{3} \mathrm{CH}_{3} \\
92 \\
\mathrm{C}_{2} \mathrm{H}_{5} \mathrm{CII}\left(\mathrm{CH}_{3}\right)_{2} \\
8\end{array}$ \\
\hline 6 & $\begin{array}{c}\mathrm{CH}_{3}\left(\mathrm{CH}_{2}\right)_{5} \mathrm{OH} \\
49 \\
n-\mathrm{C}_{3} \mathrm{H}_{7} \mathrm{CHI}\left(\mathrm{CiH}_{3}\right) \mathrm{CH}_{2} \mathrm{OH} \\
33 \\
\left(\mathrm{C}_{2} \mathrm{H}_{5}\right)_{2} \mathrm{CIICH}_{2} \mathrm{OH} \\
18\end{array}$ & \\
\hline
\end{tabular}

$10 \mathrm{~g}$-catalyst $\cdot \mathrm{h} \cdot \mathrm{mol}^{-1}$ surface ethyl species could react with surface $\mathrm{CH}_{x}$ to form higher hydrocarbons and/or could react with the adsorbed $\mathrm{CO}$ to form $\mathrm{C}_{3}$ oxygenated compounds, followed by dehydration to $\mathrm{C}_{3}$ hydrocarbons.

Selectivities for the ethene conversion to $\mathrm{C}_{3}$ compounds were rather low, however, owing to the high activity of the catalyst without $\mathrm{K}$ for the simple hydrogenation of ethene. The addition of $\mathrm{KCl}$ significantly suppressed the rate of hydrogenation of ethene to ethane, resulting in the improvement of the selectivity toward hydrocarbonylation by a factor of 3 . This may be closely related to the promotion of alcohol selectivity from $\mathrm{CO}-\mathrm{H}_{2}$ by the addition of $\mathrm{K}$.

Hydrocarbonylation of higher alkenes also took place over the Mocatalysts. Isomers branching in the 2-position were obtained together with those with straight chain. Table 6 shows the effect of addition of propene $(1.0 \mathrm{~mol} \%)$ to $\mathrm{CO}-\mathrm{H}_{2}$ on the isomer distribution in butanols. Along with the increase in the yield of butanols, their isomer distribution was hardly changed by the addition of propene, indicating that the butanols from propene hydrocarbonylation were very similar, in the isomer distribution, to those from $\mathrm{CO}-\mathrm{H}_{2}$.

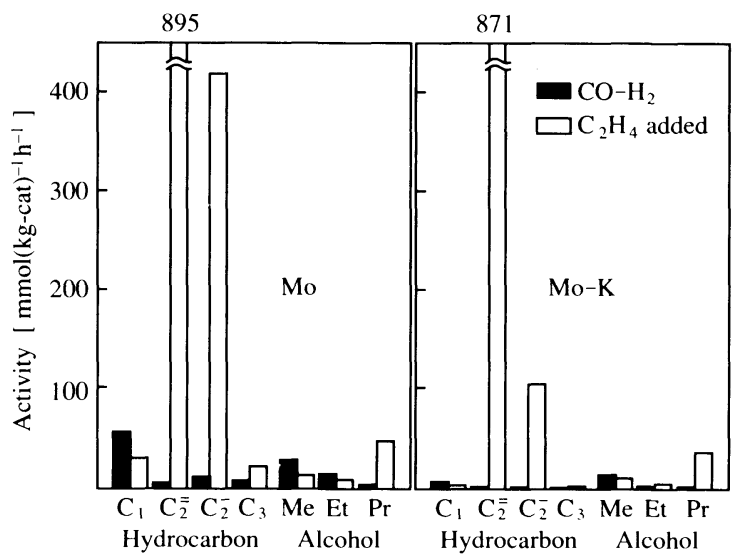

Catalysts: $\mathrm{Mo}(20 \mathrm{wt} \%) / \mathrm{SiO}_{2}$ and $\mathrm{Mo}(20 \mathrm{wt} \%)-\mathrm{K}(1.63$ $\left.\mathrm{wt}^{\circ} \%\right) / \mathrm{SiO}_{2}$; Reaction conditions: $473 \mathrm{~K}, 1.6 \mathrm{MPa}\left(\mathrm{H}_{2} /\right.$ $C . \mathrm{O}=\mathrm{l}), W / F=10 \mathrm{~g}$-(at. $\cdot \mathrm{h} \cdot \mathrm{mol}^{-1}$.

Fig. 5 Influence of $A$ ddition of Ethene( $\left.1.0-1.3 \mathrm{~mol}^{\%}\right)$ to $\mathrm{CO}-\mathrm{I}_{2}$ Reactant Gas on Product Distribution

Table 6 Influence of Propene ( $1.0 \mathrm{~mol} \%)$ Addition on Isomer Distribution in Product Butanols (2-methyl-l-propanol/1-butanol)

\begin{tabular}{|c|c|c|c|c|}
\hline \multirow{3}{*}{ Feed } & \multicolumn{4}{|c|}{ Catalyst, $\mathrm{K}[\mathrm{wt} \%]$} \\
\hline & \multicolumn{2}{|r|}{0} & \multicolumn{2}{|r|}{1.63} \\
\hline & $\mathrm{CO}-\mathrm{H}_{2}$ & $\mathrm{CO}-\mathrm{H}_{2}-\mathrm{C}_{3} \mathrm{I}_{6}$ & $\mathrm{CO}-\mathrm{II}_{2}$ & $\mathrm{CO}-\mathrm{H}_{2}-\mathrm{C}_{3} \mathrm{H}_{6}$ \\
\hline Yield of butanols $\left[\mathrm{mmol} \cdot(\mathrm{kg} \text {-catalyst })^{-1} \cdot \mathrm{h}^{-1}\right]$ & 1.2 & 3.3 & 2.5 & 18 \\
\hline Selectivity to 2-methyl-1-propanol [mol\%] & 49 & 52 & 30 & 32 \\
\hline
\end{tabular}

Catalyst: Mo $(20 \mathrm{wt} \%) / \mathrm{SiO}_{2}$. Reaction conditions: $523 \mathrm{~K}, 1.6 \mathrm{MPa}\left(\mathrm{H}_{2} / \mathrm{CO}=1\right), W / F=10 \mathrm{~g}-\mathrm{catalyst}^{\circ} \cdot \mathrm{h} \cdot \mathrm{mol}^{-1}$. 
This similarity was found to hold in the temperature range of $423-573 \mathrm{~K}$. Over both catalysts the selectivity to 2-methyl-1-propanol similarly decreased on lowering the temperature. These findings imply that the higher alcohol formation from $\mathrm{CO}-\mathrm{H}_{2}$ proceeded by way of the same intermediate as the alkene hydrocarbonylation; carbon monoxide inserted into an alkyl-metal bond to form acyl species which was subsequently hydrogenated to the alcohol product.

In contrast to the addition of alkenes, the addition of methanol $(2.0 \mathrm{~mol} \%)$ resulted in no significant change in the formation of the homologation product ethanol ${ }^{24)}$. At $473 \mathrm{~K}$ over the $\mathrm{KCl}$ promoted and unpromoted catalyst, the methanol conversion to ethanol was estimated at $0.3 \%$ and $0.1 \%$, respectively, and the ethene conversion to propanol was found to be $3.4 \%$ and $3.5 \%$, respectively. Hence it is unlikely that the homologation reaction of alcohols to higher alcohols contributes significantly to the production of $\mathrm{C}_{2}+$ higher alcohols from $\mathrm{CO}-\mathrm{H}_{2}$. This result is consistent with the findings that $\mathrm{C}_{2}+$ alcohols/methanol ratio was virtually independent of contact time (Fig. 4).

The change in the yields of the products caused by the addition of acetaldehyde was studied. Neither of the Mo catalysts showed any significant activity for the incorporation of aldehydes for the chain growth of alcohols. However, both catalysts exhibited a significant activity for the acetaldehyde conversion to $\mathrm{C}_{4}$ oxygenated compounds, namely, crotonaldehyde, butyraldehyde, and butanol. This suggests the occurrence of aldol condensation of acetaldehyde. Because the addition of $\mathrm{KCl}$ causes a sharp decrease in the ratio of $\mathrm{C}_{4}$ oxygenates and hydrocarbons derived from acetaldehyde to remaining acetaldehyde (4.0 to 15), the aldol condensation appears to be catalyzed by acid sites on the surface. As shown in Table 2, however, the alcohol chain growth in the $\mathrm{CO}-\mathrm{H}_{2}$ reaction was promoted by adding $\mathrm{KCl}$. Hence it is unlikely that aldol condensation could be important for chain growth to form higher alcohols.

A different type of evidence against aldol condensation is offered by the carbon chain structure of the alcohols. The presence of 2-ethyl-1butanol (Table 5) cannot be explained by aldol condensation of $\mathrm{C}_{5}$ aldehyde with $\mathrm{C}_{1}$ intermediates. In contrast, the hydrocarbonylation mechanism can account for its formation, by assuming $\mathrm{CO}$ insertion into $\left(\mathrm{C}_{2} \mathrm{H}_{5}\right)_{2} \mathrm{CH}-\mathrm{M}$ bond which could be formed through $\sigma-\pi$ interconversions of coordinated $n$-pentyl (Eq. (8)). The hypothesis of the insertion of $\mathrm{CO}$ into a growing alkyl-metal bond has been proposed by many authors ${ }^{25}$ to explain the formation of oxygenated products over group VIII noble metal based metal catalysts.

$$
\begin{aligned}
& \mathrm{C}_{2} \mathrm{H}_{5} \mathrm{CH}_{2} \mathrm{CH}_{2} \mathrm{CH}_{2}-\mathrm{M} \longrightarrow \\
& \mathrm{C}_{2} \mathrm{H}_{5} \mathrm{CH}_{2}\left(\mathrm{CH}_{3}\right) \mathrm{CH}-\mathrm{M} \\
& \longrightarrow\left(\mathrm{C}_{2} \mathrm{H}_{5}\right)_{2} \mathrm{CH}-\mathrm{M} \stackrel{\left(\mathrm{CO} . \mathrm{H}_{2}\right.}{\longrightarrow}\left(\mathrm{C}_{2} \mathrm{H}_{5}\right)_{2} \mathrm{CHCH}_{2} \mathrm{OH}
\end{aligned}
$$

\section{Reaction Mechanism of CO Hydrogenation}

\section{1 Mechanism for Branchings}

As has been described above, isomer distributions in alcohols and alkanes obtained with $\mathrm{SiO}_{2}$ supported Mo catalysts were different. The formation of alcohols with branching in the 2position can be accounted for by Eq. (10); the insertion of $\mathrm{CO}$ into the secondary alkyl-metal bond leads to branched alcohols. Eqs. (11) and (12) shows the formation of straight chained and branched alkanes, respectively.

The difference in the selectivity to branched products between hydrocarbons and alcohols suggests that alcohols are formed at sites different from those for hydrocarbon formation, that is, the sites, M', in Eqs. (9) and (10) differ from the sites, $M$, in Eqs. (11) and (12). From the findings which have been described above, there is good reason to suppose that $\mathrm{M}^{\prime}$ is $\mathrm{MoO}_{2-x}$ and $\mathrm{M}$ metallic Mo. It has been found that the metal electron density determines the secondary/primary ratio of coordinated alkyls ${ }^{26)}$. The $\mathrm{MoO}_{2-x}$ site should be less electron-rich than metallic Mo, allowing the formation of secondary alkyl groups (Eq. (9)). In contrast the pathway Eq. (12) is supposed to be infrequent since secondary alkyl groups should be disadvantageous on electron-rich sites of metallic Mo.

$$
\mathrm{RCH}_{2} \mathrm{CH}_{2}-\mathrm{M}^{\prime} \stackrel{\mathrm{CO}}{\longrightarrow} \mathrm{RCH}_{2} \mathrm{CH}_{2} \mathrm{C}_{\mathrm{O}}-\mathrm{M}^{\prime} \stackrel{\mathrm{H}_{2}}{\longrightarrow}
$$$$
\mathrm{RCH}_{2} \mathrm{CH}_{2} \mathrm{CH}_{2} \mathrm{OH}
$$

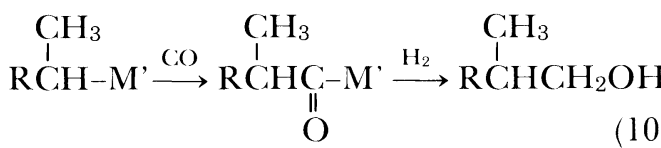

$$
\begin{aligned}
& \mathrm{RCH}_{2} \mathrm{CH}_{2}-\mathrm{M} \stackrel{\mathrm{CH}_{2}}{\longrightarrow} \mathrm{RCH}_{2} \mathrm{CH}_{2} \mathrm{CH}_{2}-\mathrm{M} \stackrel{\mathrm{H}_{2}}{\longrightarrow} \\
& \mathrm{RCH}_{2} \mathrm{CH}_{2} \mathrm{CH}_{3}
\end{aligned}
$$






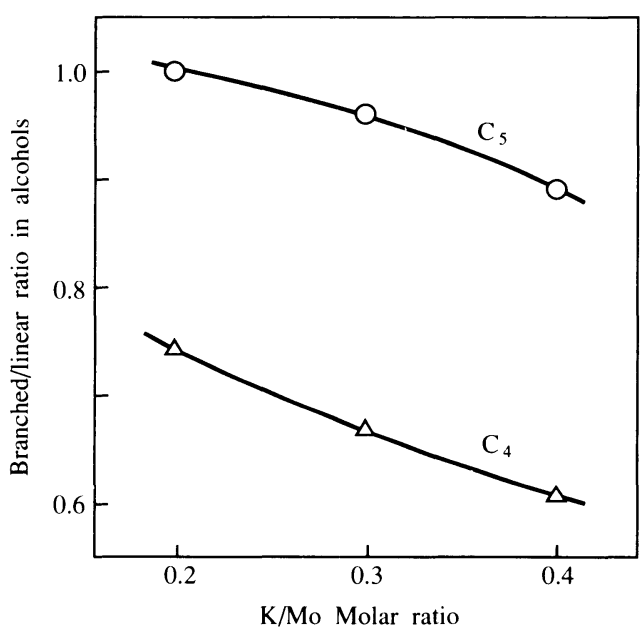

Catalysts: $\mathrm{Mo}(20 \mathrm{wt} \%) / \mathrm{SiO}_{2}$; Reaction conditions: $573 \mathrm{~K}$, 1.6 $\mathrm{MPa}\left(\mathrm{H}_{2} / \mathrm{CO}=\mathrm{l}\right), W / F=10 \mathrm{~g}$-cat. $\cdot \mathrm{h} \cdot \mathrm{mol}^{-1}$.

Fig. 6 Effect of K Content on Branched/Linear Ratio $\mathrm{C}_{4}$ and $\mathrm{C}_{5} \mathrm{Alcohols}$

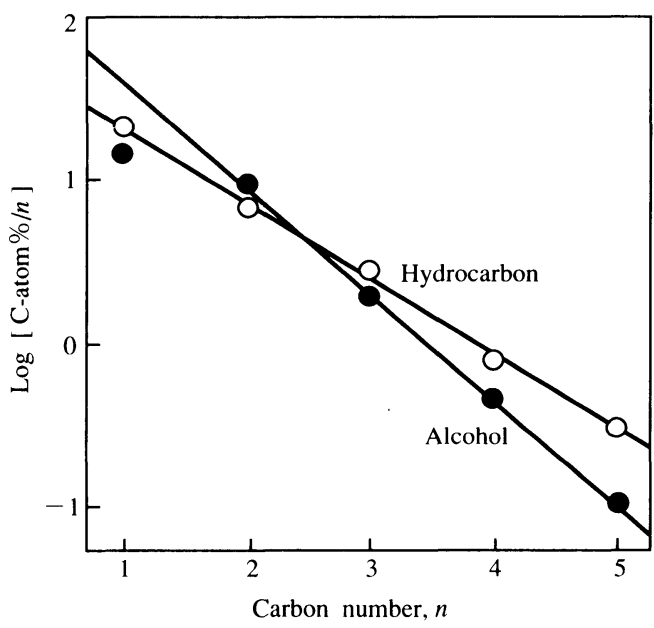

Ciatalyst: $\mathrm{Mo}(10 \mathrm{wt} \%)-\mathrm{K}(1.63 \mathrm{wt} \%) / \mathrm{SiO}_{2} ;$ Reaction conditions: $573 \mathrm{~K}, 1.6 \mathrm{MPa}\left(\mathrm{H}_{2} / \mathrm{CO}=1\right), W / F=10$ g-cat. $\mathrm{h} \cdot \mathrm{mol}^{-1}$.

Fig. 7 Anderson-Schulz-Flory Plots for Hydrocarbons and Alcohols

In Fig. 6 the branched/linear ratios in $\mathrm{C}_{4}$ and $\mathrm{C}_{5}$ alcohols are plotted against the content of $\mathrm{K}$ added to $\mathrm{Mo}(20 \mathrm{wt} \%) / \mathrm{SiO}_{2}$ catalysts. With increasing $\mathrm{K}$ content, the selectivity to branched alcohols significantly decreased. The decrease can be accounted for by $\mathrm{K}$-induced increase in electron density of molybdenum in $\mathrm{MoO}_{2-x}\left(\mathrm{M}^{\prime}\right)$ species, which makes the reaction Eq. (9) more favorable than Eq. (10). In contrast with this observation, Vedage et al. found that the yield of 2-methyl-1propanol over $\mathrm{Cu} / \mathrm{ZnO}$ was enhanced by addition of Cs and explained its formation by assuming aldol condensation of aldehydic intermediates with $\mathrm{C}_{1}$ intermediates ${ }^{27}$.

\section{2 Anderson-Schulz-Flory Distributions for} Hydrocarbons and Alcohols

Anderson-Schulz-Flory plots for hydrocarbons and alcohols produced over $\mathrm{Mo}(10 \mathrm{wt} \%)-\mathrm{K}(1.63$ wt\%) $/ \mathrm{SiO}_{2}$ catalysts are shown in Fig. 7. Over Mo catalysts, the carbon number distribution obeyed an Anderson-Schulz-Flory type distribution for hydrocarbons and alcohols, respectively, except for methanol. Because the yield of methanol was far below the equilibrium value, the deviation cannot be caused by thermodynamic control. This deviation could be due to a pathway for methanol formation different from other products; methanol is the only product that does not involve the cleavage of carbon-oxygen bond of CO. Over our Mo catalysts, the probability of the chain growth, $\alpha$, was $0.48-0.32$ for hydrocarbons and $0.32-0.14$ for alcohols; although the $\alpha$ values were dependent on the reaction conditions such as temperature and pressure and $\mathrm{K}$ content of the catalysts, the $\alpha$ value for alcohols was always smaller than that for hydrocarbons.

One might wonder that the difference in the $\alpha$ value between hydrocarbons and alcohols is attributed to the difference in the carbon-chain growth step between these products. However, it is thought that this is not the case. The chain propagation of hydrocarbons is represented by the $\mathrm{CH}_{2}$ insertion steps in Eqs. (11) and (12). These steps are followed by hydrogenolysis to give alkanes (Eqs. (11) and (12) or $\beta$-elimination to give 1 -alkenes. We consider that the alkyl groups thus formed on the metallic site, $\mathrm{M}$, migrates to the $\mathrm{MoO}_{2-x}$ site, $\mathrm{M}$ ', and is subject to $\mathrm{CO}$ insertion to give alcohols (Eqs. (9) and (10)). If the chain propagation of alkyl groups of alcohols occurred on $\mathrm{MoO}_{2-x}$, we should observe alcohols branching in the 3 or further positions according to the following Eq. (13).

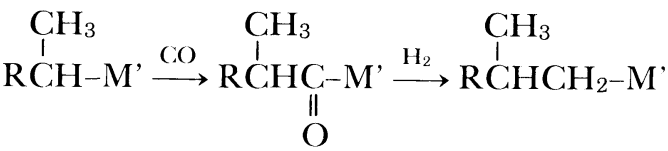

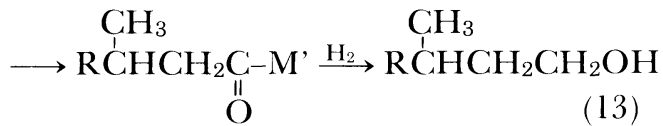

Table 7 shows the dependence of the yields of hydrocarbonylation and hydrogenation products on the carbon number of alkenes which were added to the reactant $\mathrm{CO}-\mathrm{H}_{2}$ gas $^{28)}$. The yields from added alkenes were determined from the increase in the yields of corresponding products as a result of 
Table 7 Dependence of Alkene Conversion on Carbon Number

\begin{tabular}{|c|c|c|c|c|c|c|}
\hline \multirow{3}{*}{$\begin{array}{l}\text { Alkene } \\
\mathrm{C}_{n}\end{array}$} & \multicolumn{6}{|c|}{ Catalyst, K [wt $\%]$} \\
\hline & \multicolumn{3}{|c|}{0} & \multicolumn{3}{|c|}{1.63} \\
\hline & $\begin{array}{c}\mathrm{C}_{n+1} \text { alcohols } \\
\text { yield }(\mathrm{A}) \\
{[\%]} \\
\end{array}$ & $\begin{array}{c}\mathrm{C}_{n} \text { alkane } \\
\text { yield }(\mathrm{P}) \\
{[\%]} \\
\end{array}$ & $\begin{array}{c}\text { Ratio } \\
\mathrm{A} / \mathrm{P}\end{array}$ & $\begin{array}{c}\mathrm{C}_{n+1} \text { alcohols } \\
\text { yield }(\mathrm{A}) \\
{[\%]} \\
\end{array}$ & $\begin{array}{c}\mathrm{C}_{n} \text { alkane } \\
\text { yield }(\mathrm{P}) \\
{[\%]}\end{array}$ & $\begin{array}{c}\text { Ratio } \\
\mathrm{A} / \mathrm{P}\end{array}$ \\
\hline $\begin{array}{l}\text { Ethene } \\
\text { Propene } \\
\text { 1-Pentene }\end{array}$ & $\begin{array}{l}3.4 \\
0.53 \\
0.031\end{array}$ & $\begin{array}{c}30 \\
20 \\
5.8\end{array}$ & $\begin{array}{l}0.11 \\
0.027 \\
0.0053\end{array}$ & $\begin{array}{l}3.3 \\
0.20\end{array}$ & $\begin{array}{l}8.8 \\
6.3\end{array}$ & $\begin{array}{l}0.38 \\
0.032\end{array}$ \\
\hline
\end{tabular}

addition of each alkene. As the carbon number of the alkene increased, activities for both hydrocarbonylation and hydrogenation decreased. This was associated with the marked decrease in the ratio of hydrocarbonylation to hydrogenation, suggesting that the insertion of molecular $\mathrm{CO}$ to alkyl-metal bonds is more retarded for the longer alkyl chain. It is conceivable that this difference in the carbon number dependence between hydrocarbonylation and hydrogenation results in the difference in the $\alpha$ between alcohols and hydrocarbons even if alcohols and hydrocarbons follow a common chain growth step, namely, the insertion of a methylene unit to an alkyl group.

\section{3 Dual-site Mechanism for Alcohols and $\mathbf{H y}$ - drocarbons Formation}

As described above, oxidized Mo species, $\mathrm{MoO}_{2-x}$, should be responsible for the formation of alcohols, whereas metallic Mo species is necessary for the formation of both hydrocarbons and oxygenates. It is known that metallic Mo readily dissociates $\mathrm{CO}$ at room temperature and that oxidation of the surface inhibits the dissociative component of adsorption and increases the associative component ${ }^{29)}$. Presumably $\mathrm{C}_{2}+$ alcohols are formed via a dual-site mechanism as follows. First, $\mathrm{CO}$ adsorbed dissociatively on metallic Mo to form surface carbide, which is hydrogenated to give carbene and/or methyl species, while carbon monoxide is nondissociatively adsorbed on $\mathrm{MoO}_{2-x}$ sites. The alkyl chain growth mechanism must be identical for hydrocarbons and alcohols. The chain growth is likely to occur on the same metallic Mo site, where carbene insertion into an alkyl-metal bond leads to a longer alkyl group.

It appears that the termination steps for alcohols and hydrocarbons occur on different sites. Hydrocarbons should be formed via hydrogenolysis of alkyl-metal bond and/or $\beta$-C- $\mathrm{H}$ abstraction on metallic Mo sites, whereas the insertion of $\mathrm{CO}$ giving rise to alcohols occurs on $\mathrm{MoO}_{2-x}$. $\mathrm{K}$ is effective in retarding hydrogenolysis of surface alkyls, resulting in the improvement in the



Scheme 1 Reaction Pathway of CO Hydrogenation on $\mathrm{SiO}_{2}$-supported Molybdenum Catalysts

selectivity to alcohols. Alkyl groups formed on metallic Mo are assumed to migrate to a molecular $\mathrm{CO}$ on $\mathrm{MoO}_{2-x}$ species. A similar dual-site mechanism has been proposed for $\mathrm{Rh}$ catalysts, yielding $\mathrm{C}_{2}$ oxygenates selectively ${ }^{30}$. In a mechanistic study on CO hydrogenation over Fe catalysts, Huff and Satterfield found two sites over Fe catalysts with one site producing l-alkenes, alkanes and oxygenates, and the other not producing oxygenates ${ }^{31)}$. Anderson and Ekerdt claimed a similar mechanism for the carbon chaingrowth, occurring on one site to produce alcohols and on the other site to produce hydrocarbons ${ }^{32}$. These sites may differ only in the type of termination step allowed, alkyl hydrogenation/ dehydrogenation to hydrocarbon products $v s$. CO insertion leading to oxygenates. They suggested the difference of Fe valence between sites forming hydrocarbons and sites forming alcohols.

Methanol is the only product that does not involve the carbon-oxygen bond of $\mathrm{CO}$ and assumed to be formed solely on $\mathrm{MoO}_{2-x}$. The activity change with processing time is consistent with this mechanism. In the initial stage of the $\mathrm{CO}-\mathrm{H}_{2}$ reaction the yield of methanol was noticeably low compared to $\mathrm{C}_{2}+$ alcohols. As the $\mathrm{CO}-\mathrm{H}_{2}$ catalytic run was continued, the increase in the yield of methanol was more remarkable than that of $\mathrm{C}_{2}+$ alcohols, resulting in the decrease in the $\mathrm{C}_{2}+/ \mathrm{C}_{1}$ ratio for alcohols. This is interpreted in terms of the conditioning of the catalyst surface; 
the amount of $\mathrm{MoO}_{2-x}$ was increased through reduction of $\mathrm{MoO}_{2}$ by $\mathrm{CO}$ according to Eq. (7).

Thus the reaction scheme for hydrogenation of CO over the Mo catalysts producing hydrocarbons and alcohols would be summarized as shown in Scheme 1.

\section{References}

1) Klier, K., "Catalysis of Organic Reactions", ed. by Moser, W. R., Marcel Dekker, New York (1981), p. 195.

2) Xu, X., Doesburg, E. B. M., Scholten, J. J. F., Catal. Today, 2, 125 (1987).

3) Natta, G., Colombo, U., Pasquon, I., "Catalysis", ed. by Emmett, P. H., Reinhold, New York (1957), Vol. V, p. 131

4) Sugier, A., Freund, E., U. S. Pat. 4122110 (1978).

5) Uchiyama, S., Kawata, N., Sekiyu Gakkaishi, 33, (1), 1 (1990).

6) Shultz, J. F., Karn, F. S., Anderson, R. B., U. S. Bureau of Mines Reports, 6974, l (1967)

7) Saito, M., Anderson, R. B., J. Catal., 51, 1 (1978).

8) Tatsumi, 'T., Muramatsu, A., Tominaga, H., Appl. Catal., 27, 69 (1982).

9) Tatsumi, 'T., Muramatsu, A., Tominaga, H., Sekiyu Gakkaishi, 32, (1), 43 (1989).

10) Tatsumi, T., Muramatsu, A., Tominaga, H., Chem. Lett., 685 (1984)

11) Tatsumi, T., Muramatsu, A., Fukunaga, T., Tominaga, H., Polyhedron, 5, 257 (1986).

12) Tatsumi, T., Muramatsu, A., Tominaga, H., J. Catal., 10. 553 (1986).

13) Tatsumi, T., Muramatsu, A., Tominaga, H., Appl. Catal., 34, 77 (1987)

14) Muramatsu, A., Tatsumi, T., Tominaga, H., Bull. Chem. Soc. Jpn., 60, 3157 (1987).

15) Quarderer, G. J., EPO-0119609 (1984); Kinkade, N. E., EPO-0149255 (1985); Kinkade, N. E., EPO-0149256 (1985); Stevens, R. R., EPO-0172431 (1986).
16) Muralidhar, G., Concha, B. E., Bartholomew, G. L., Bartholomew, C. H., J. Catal., 89, 274 (1984).

17) 'Tatsumi, T., Muramatsu, A., Yokota, K., Tominaga, H., Stud. Surf. Sci. Catal., 36, 219 (1988).

18) Concha, B. F., Bartholomew, C. H., J. Catal., 79, 327 (1983).

19) Leclercq, L., Imura, K., Yoshida, S., Boudart, M., "Preparation of Catalysts II", eds. by Delmon, B. et al., Elsevier, Amsterdam (1978), p. 627.

20) Ranhotra, G. S., Bell, A. T., Reimer, J. A., J. Catal., 108, 49 (1987).

21) Bowker, M., Hyland, J. N. K., Vandervell, H. D., Waugh, K. C., Proc. 8th Intern. Congr. on Catal., Verlag Chemie, Weinheim (1984), Vol. 2, p. 35

22) Silver, R. G., Ion, C. J., Ekerdt, J. G., J. Catal., 118, 400 (1989).

23) Maruyama, K., Hattori, H., Tanabe, K., Bull. Chem. Soc. Jpn., 50, 86 (1977).

24) Tatsumi, T., Muramatsu, A., Yokota, K., Tominaga, H., J. Mol. Catal., 41, 129 (1987); J. Catal., 115, 388 (1989).

25) Rabo, J. A., Risch, A. P., Poutsma, M. L., J. Catal., 53, 295 (1978); Takeuchi, A., Katzer, J. R., J. Phys. Chem., 86, 2438 (1982); Sachtler, W. M. H., Ichikawa, M., J. Phys. Chem., 90, 4752 (1986); Favre, T. L. F., Van der Lee, G., Ponec, V., J. Chem. Soc., Chem. Commun., 230 (1985)

26) Tamao, K., Kiso, Y., Sumitani, K., Kumada, M., J. Am. Chem. Soc., 94, 9268 (1982).

27) Vedage, G. A., Himelfarb, P., Simmons, G. W., Klier, K., ACS Symp. Ser., 279, 295 (1986).

28) Muramatsu, A., Tatsumi, T., Tominaga, H., J. Phys. Chem., 96, 1334 (1992).

29) Ko, E. I., Maddix, R. J., Surf. Sci., 109, 221 (1981).

30) Watson, P. R., Somorjai, G. A., J. Catal., 72, 347 (1981), 74, 282 (1982); Driessen, J. M., Poels, E. K., Hindermann, J. P., Ponec, V., J. Catal., 82, 26 (1983); van den Berg, F. G. A., Glezer, J. I. F., Sachtler, W. M. H., J. Catal., 93, 340 (1985).

31) Huff Jr., G. A., Satterfield, C. N., J. Catal., 85, 370 (1984).

32) Anderson, K. G., Ekerdt, J. G., J. Catal., 95, 602 (1985). 
要 旨

\section{合成ガスからの混合アルコール合成用モリブデン触媒}

辰巳 敬, 村松淳司, 冨永博夫

東京大学工学部合成化学科, 113 東京都文京区本郷 7-3-1

シリカゲルを担体としてモリブデン触媒を調製したところ， 合成ガスからの混命アルコール合成に活性の高い触媒系が実現 した。 $\mathrm{KCl}$ の添加は $\mathrm{CO}$ 転化率を低下させ, とりわけ炭化水 素の生成を抑制し，アルコール選択率向上に効果があった。 $5.0 \mathrm{MPa}, 573 \mathrm{~K}, W / F=1.4 \mathrm{~g}$-触媒・時間/モルに打いて 420 $\mathrm{g} / \mathrm{kg}$-触媒/時間という高いアルコール生成活性が達成された。 アルコールの生成には水素還元後, 金属モリブデンならびに $\mathrm{MoO}_{2}$ の両者が存在することが必要であることが分かった。 $\mathrm{K}$ を添加するとモリブデンの金属への完全還元が抑制され，この 際アルコールの生成増加が認められた。アルコール収量は反応 時間とともに顕著に増加することから, $\mathrm{CO}$ 水素化反応中にア ルコール合成の活性種が生成することが示された。触媒を $\mathrm{CO}, \mathrm{CO}-\mathrm{H}_{2}$, ブタンー水素で前処理した時の効果, $\mathrm{Mo}(3 d)$ の XPS スペクトルを調べることにより，CO 水素化反応中， $\mathrm{CO}$ で $\mathrm{MoO}_{2}$ が還元されて酸素欠陥 $\mathrm{MOO}_{2-x}$ が生成し, こ
れがアルコール合成活性の向上をもたらすことが示唆された。 一方，炭化水素合成は金属モリブデンのみによるものと思われ る。プローブ分子を $\mathrm{CO}-\mathrm{H}_{2}$ ガスに添加することにより， $\mathrm{C}_{2}$ 以上のアルコールの生成はアルケンのヒドロカルボニル化と同 様の中間体を経由していることが明らかになった。シリカゲル 担持モリブデン触媒上でのアルコール生成機構としてデュアル サイト機構を提案した。すなわち，金属モリブデン上で CO が解離し, 表面カーバイド種を生成し, 水素化によりカルベン やメチル種を与える。メチレンの表面アルキル種への挿入と続 いての水素化分解や脱水素による炭化水素生成もまた金属モリ ブデン上で起こるが, $\mathrm{CO}$ 挿入によるアルコール生成は $\mathrm{MoO}_{2-x}$ により触媒される。K $\mathrm{K}$ はアルキル種の水素化分解の抑制によ りアルコール選択率を向上せしめる効果を持つ。このデュアル サイト機構により，枝分かれ化合物への選択率が炭化水素とア ルコールで大きく異なっていることも説明できる。

\section{Keywords}

Molybdenum catalyst, Silica gel, Carbon monoxide, Hydrogenation, Alcohol 